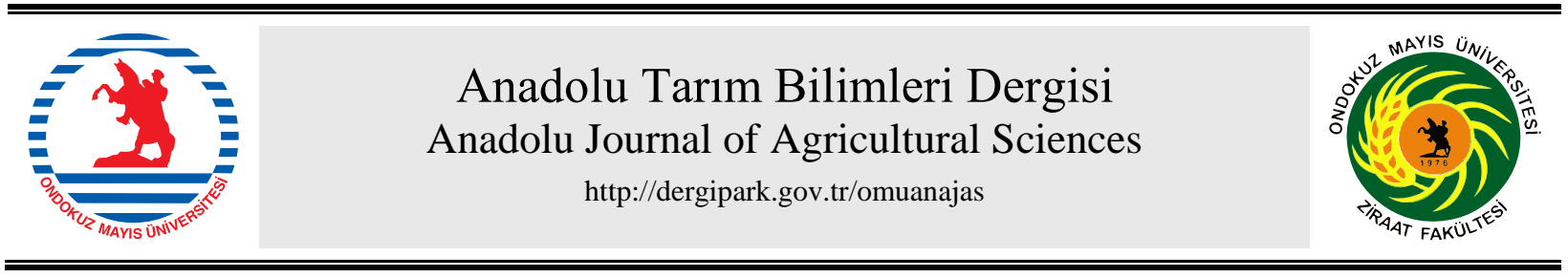

Araştırma/Research

Anadolu Tarım Bilim. Derg./Anadolu J Agr Sci, 35 (2020)

ISSN: 1308-8750 (Print) 1308-8769 (Online)

doi: 10.7161/omuanajas.790698

\title{
Kuraklık stresi altındaki buğdayda eksojen Glisin Betain’in fizyolojik ve biyokimyasal etkileri
}

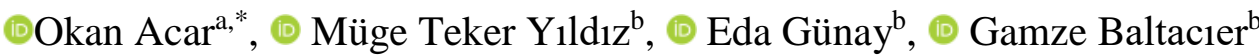 \\ ${ }^{a}$ Çanakkale Onsekiz Mart Üniversitesi, Fen Edebiyat Fakültesi, Biyoloji Bölümü, Çanakkale, Türkiye \\ ${ }^{b}$ Çanakkale Onsekiz Mart Üniversitesi, Lisansüstü Eğitim Enstitüsü, Biyoloji Anabilim Dall, Çanakkale, Türkiye
}

*Sorumlu yazar/corresponding author: oacar@comu.edu.tr

Geliș/Received 04/09/2019 Kabul/Accepted 08/09/2020

\begin{abstract}
ÖZET
Kuraklık, bitki büyümesini ve verimini olumsuz etkileyen bir abiyotik stres faktörüdür. Buğday gibi tahıllar kuraklık stresinden olumsuz etkilendiklerinden verim azalmaktadır. İyi bir ozmo-tolerant olan Glisin-Betain (GB) ozmotik stres koşullarında eksojen olarak uygulandığında yaprak dokularına kolaylıkla alınır, kloroplastlarda fotosentetik aktivite ve zar bütünlüğünün sürdürülmesini sağlar ve membran zararını azaltır. Bu çalışmada $5 \mathrm{mM}$ GB uygulamasının kuraklığa farklı toleransa sahip iki buğday çeşidinde (kurağa duyarlı Sultan-95, kurağa-dayanıklı Tosunbey) kök ve gövde uzunluğu, klorofil miktarı (SPAD), bağıl su içeriği, lipit peroksidasyon (TBARS), hücre zarı geçirgenliği (HZG), hidrojen peroksit $\left(\mathrm{H}_{2} \mathrm{O}_{2}\right)$ ve antioksidan savunma sistemi enzim aktiviteleri (peroksidaz (POX), askorbat peroksidaz (APX), glutatyon redüktaz (GR), katalaz (CAT)) üzerine etkisi araştırılmıştır. Sonuçlarımıza göre, eksojen GB uygulaması ile her iki çeşit kuraklığa bağlı klorozisten ve kök uzunluğundaki inhibisyondan korunmuştur. Her iki çeşitte kuraklığa bağlı oksidatif stres nedeniyle TBARS ve $\mathrm{H}_{2} \mathrm{O}_{2}$ miktarının eksojen $\mathrm{GB}$ uygulamasıyla azaldığı belirlenmiştir. Oksidatif stresin bastırılmasında, $\mathrm{H}_{2} \mathrm{O}_{2}$ detoksifikasyonunun Tosunbey çeşidinde POX aktivitelerindeki artış ile Sultan95’te ise APX ve CAT aktivitelerindeki artış ile gerçekleştiği saptanmıştır. Sonuç olarak, eksojen GB uygulaması her iki buğday çeşidinde kuraklık stresiyle ortaya çıkan oksidatif zarardan korunma sağlamıştır.
\end{abstract}

Physiological and biochemical effects of exogenous Glycine Betaine in wheat under drought stress

\section{ABSTRACT}

Drought is an abiotic stress factor that negatively affects plant growth and productivity. Drought stress reduces the yield of cereals such as wheat. Glycine-Betaine (GB), which is a good osmo-tolerant, is easily absorbed into leaf tissues when applied exogenously under osmotic stress conditions. Thus, it maintains photosynthetic activity and membrane integrity in chloroplasts and reduces membrane damage. In this study, root and stem length, chlorophyll content (SPAD), relative water content, lipid peroxidation (TBARS), cell membrane permeability (HZG), hydrogen peroxide $\left(\mathrm{H}_{2} \mathrm{O}_{2}\right)$ and antioxidant defense system enzyme activities (peroxidase (POX), ascorbate peroxidase (APX), glutathione reductase (GR), catalase (CAT)) were investigated in two wheat varieties (drought tolerant, Sultan-95; drought-resistant, Tosunbey) of $5 \mathrm{mM}$ GB application. According to our results, both varieties were protected from drought-related chlorosis and root length inhibition with exogenous GB application. It was determined that the amount of TBARS and $\mathrm{H}_{2} \mathrm{O}_{2}$ increased with drought-dependent oxidative stress in both wheat varieties decreased with exogenous GB application. In reducing oxidative stress, it was determined that $\mathrm{H}_{2} \mathrm{O}_{2}$ detoxification occurred with the increase in POX activities in Tosunbey variety and with the increase in APX and CAT activities in Sultan-95. As a result, exogenous GB application provided a protection from oxidative damage caused by drought stress in both wheat varieties.
Anahtar Sözcükler:

Kuraklik stresi

Antioksidan savunma sistemi

Buğday

Glisin-Betain
Keywords:

Drought stress

Antioxidant defense

system

Wheat

Glycine-Betaine

(C) OMU ANAJAS 2020 


\section{Giriş}

Birleşmiş Milletler Gıda ve Tarım Örgütü (FAO) tarafindan açıklanan rapora göre, hızla artan dünya nüfusunu beslemek için daha fazla sürdürülebilir gida kaynağına ihtiyaç duyulacaktır. Diğer yandan, Dünya nüfusunun 2050 yılına kadar yaklaşık 9 milyara ulaşacağı ve ürün verimliliğinin iki katına çıkması gerektiği de kabul edilmektedir. (Jaganathan ve ark., 2018). Gelecekte, tahıl yetiştirmek için gerekli arazilerin yetersiz kalabileceği ve bu konunun artan gida ihtiyacının karşılanması için bir problem olabileceği düşünülmektedir. İklim değişiklikleri, tarım arazilerinin azalması, tarımda kullanılabilecek su kaynaklarının yetersizliği, biyotik ve abiyotik stres etmenlerinin artması, giderek şiddetlenen küresel iklim değişikliği tarım ve gıda üretimi için önemli engeller arasındadır (Mickelbart ve ark., 2015). Dünya'da ekilebilir tarım arazileri 2000 yllında 4.92 milyar hektar iken 2017 yllında 4.83 milyar hektara gerilemiştir (FAOSTAT, 2020). Bu arazilerin üçte biri ise halen bozulmaktadır.

Tek yıllık otsu bir bitki olan buğday hem Türkiye'de hem de Dünya'nın pek çok ülkesinde temel ve stratejik bir besin maddesi olarak kullanılmaktadır. Aynı zamanda çiftlik hayvanları için yem olarak yetiștirilmektedir. Buğday; mineral maddeler, B vitamini ve mikro besin maddelerince zengin olduğundan küresel nüfusun besin ve enerji ihtiyacının büyük bir kısmını karşılamaktadır (Cummins ve Thomson, 2009). 2016 yılı verilerine göre Türkiye'nin yaklaşık olarak 200 ekmeklik buğday çeşidine sahip olduğu bildirilmiștir. Dünya genelinde en yoğun olarak üretilen ve tüketilen tahıl ürünleri buğday, pirinç ve mısırdır. Toplam tahıl alanları içerisinde ise yaklaşık \%70'lik pay ile buğday ilk sırada yer almaktadır (TMO, 2018). 2000'den 2018 yılına kadar buğday ekim alanlarımız ise \%20 azalmıştır. Buğday ekili arazilerdeki hızlı azalma beraberinde üretimde azalmaya neden olmuştur. Son yıllarda verimdeki olumlu gelişmelere rağmen, Türkiye'nin birim alan verimi, dünya ortalama veriminden daha düşüktür. İklim değişikliğiyle birlikte biyotik ve abiyotik stres faktörlerinin şiddetlenmesi buğdayın verim ve kalite özelliklerini olumsuz etkilemektedir (Gençtan ve ark., 2020).

Kuraklık, bitkinin büyüme döneminde, kuraklığın süresine ve kuraklık stresi yoğunluğuna bağlı olarak, buğdayda \%92 oranında verim azalmasına neden olmaktadır (Farooq ve ark., 2014). Bitkilerin su stresine tepkileri bitkinin türü, yaşı, büyüme ve gelişme evreleri, kuraklık seviyesi ve sürekliliğe ek olarak fiziksel faktörlere de bağlıdır. Kuraklık stresi nedeniyle, buğday tane sayısının en çok etkilendiği dönemin bitki üreme gelişiminin meydana geldiği dönem olduğu gösterilmiştir (Dolferus ve ark., 2011; Dong ve ark., 2017; Ma ve ark., 2017). Bitkinin üreme gelişimi boyunca kuraklık stresine dayanıklı buğday çeşitlerinin geliştirilmesi buğday yetiştiricilerinin öncelikli sorunları arasında yer almaktadır (Cattivelli ve ark., 2008; Mwadzingeni ve ark., 2016).

Abiyotik stresler; bitkide neden oldukları morfolojik, fizyolojik, biyokimyasal ve moleküler değişimlerle verimde azalmaya neden olurlar (Büyük ve ark., 2012). Öyle ki; fotosentetik pigmentlere, membran lipitlerine, proteinlere ve nükleik asitlere zarar vererek, bitkide normal seviyede üretilen reaktif oksijen türlerini (ROT)' nin üretimini artırırlar (Demirbaş ve Acar, 2008). ROT artışı hücrede çok ciddi hasarlara neden olur ve hücrenin ölümüne yol açabilir. Bu nedenle, kuraklığında dahil olduğu birçok abiyotik stres faktörü aynı zamanda bitkide oksidatif stres meydana getirmektedir (Moller ve ark., 2007). Bitkilerde oksidatif strese neden olan ROT, fotosentez sirasinda oksijenin suya indirgenmesi, mitokondride suyun oksidasyonu ve kloroplastlarda elektron aktarımı anında oluşmaktadır (Kacar ve ark., 2002). ROT protein, DNA, lipit ve karbonhidratlar gibi birçok biyolojik molekülün kararlı yapısını bozmaktadır. Oksijen indirgenmesinin ilk aşamasında oluşan hidroperoksil $\left(\mathrm{HO}_{2}{ }^{-}\right)$ve süperoksit radikali $\left(\mathrm{O}_{2}{ }^{-}\right)$, hücrede lipit peroksidasyonuna neden olmaktadır. Üretildiği bölgeden daha uzak mesafelere difüze olabilen ve diğerlerine kıyasla daha uzun ömürlü olan hidrojen peroksit $\left(\mathrm{H}_{2} \mathrm{O}_{2}\right)$, aminoasitlerin sülfidril ( $\mathrm{SH}$ ) gruplarının oksidasyonu aracılığıyla biyolojik toksisiteye yol açmaktadır (Dat ve ark., 2000).

Ozmotik düzenleme ile bitkideki su potansiyelini korumak önemlidir (Blum, 2017). Ozmolitler, bitkilerdeki diğer biyokimyasal reaksiyonlara müdahale etmeden abiyotik strese yanıt olarak hızla biriken uyumlu çözünen maddelerdir. Ozmolitlerin ozmotik ayarlamayı desteklemek, hücre turgorunu sürdürmek, hücresel yapıları korumak, stoma açıklığını korumak ve hücresel redoks potansiyelini düzenlemek için ozmoprotektan olarak rol oynadıkları bilinmektedir (Hare ve ark., 1998; Alves ve Setter, 2004). İyi bilinen organik ozmolitler arasinda prolin, glisin betain (GB), şekerler ve polioller bulunur (Verbruggen ve Hermans, 2008). Prolin ve GB uygulamalarını hücre zarı hasarlarını indirgediği, $\mathrm{K}^{+}$alınımını ve klorofil içeriğini artırdığı saptanmıştır (Gadallah 1999). Eksojen GB uygulaması abiyotik streslere karşı çeşitli bitki türlerinde tolerans1, bitki büyümesini ve verimi arttırabilir. GB bitkilerin yapraklarına uygulandığ zaman, yaprak dokuları tarafindan kolaylıkla alınır (Chen ve Murata, 2008).

$\mathrm{Bu}$ araştırmada kuraklığa maruz bırakılan iki buğday varyetesinde (kuraklığa dayanıklı (Triticum aestivum, cv. Tosunbey) ve duyarl (Triticum aestivum, cv. Sultan95)) GB ilavesinin kök ve gövde uzunluğu, klorofil miktarı (SPAD), bağıl su içeriği, lipit peroksidasyon (TBARS), hücre zarı geçirgenliği (HZG) ve antioksidan savunma sistemi enzim aktivitelerinde (peroksidaz (POX), askorbat peroksidaz (APX), glutatyon redüktaz 
(GR), katalaz (CAT)) neden olduğu değişimlerin belirlenmesine odaklanılmıştır.

\section{Materyal ve Yöntem}

\subsection{Bitki materyalleri ve büyüme koşulları}

Triticum aestivum L. türü, Poaceae familyasına ait olup ekmeklik buğday olarak bilinmektedir. $\mathrm{Bu}$ araştırmada kuraklığa duyarlı Sultan-95 ve kuraklığa dayanıklı Tosunbey kültür varyetelerine ait tohumlar sırasıyla Eskişehir Geçit Kuşağı Tarımsal Araştırma Enstitüsü'nden ve Ankara Tarla Bitkileri Merkez Araștırma Enstitüsü'nden temin edilmişlerdir.

Tohumların yüzey sterilizasyonu $\% 5^{\prime}$ lik sodyum hipoklorit çözeltisi ile gerçekleştirilmiştir. Nemli kurutma kâğıtları içerisinde çimlendirilen tohumlar, yıkanmış perlit bulunan saksılara transfer edilmiştir. Bitkiler İn vitro şartlardaki bitki kabininde, $24 \pm 2{ }^{\circ} \mathrm{C}$ sicaklıkta ve 16/8 saat fotoperiyotta yetiştirilmiştir. Fideler Hoagland besin solüsyonu (\%100) ile sulanmıştır (Steward, 1983). Üç haftalık fideler; hiçbir uygulama yapilmayan kontrol grubu (K), deney süresince su kıtllğı uygulanan kuraklık grubu (D), sadece glisin betain uygulanmış grup (GB) ve GB uygulaması sonrası su kıtlığ uygulanmış grup $(\mathrm{GB}+\mathrm{D})$ olmak üzere toplam 4 gruba ayrılmışlardır (Şekil 1). Glisin betain uygulaması (tween içeren $5 \mathrm{mM} \mathrm{GB}$ ) 21 günlük buğday fidelerinin yapraklarına püskürtme ile uygulanmıştır.

Bitkilerden alınan örneklerden kök-gövde uzunluğu, bağıl su içeriği testi (BSI)), klorofil miktarı (SPAD), toplam protein miktarı, hücre zarı geçirgenliği (HZG), malondialdehit miktarı (TBARS), hidrojen peroksit miktarı $\left(\mathrm{H}_{2} \mathrm{O}_{2}\right)$, katalaz (CAT), glutatyon redüktaz miktarı (GR), peroksidaz miktarı (POX), askorbat peroksidaz miktarı (APX) belirlenmiştir.

\subsection{Bitki ölçümleri ve analiz yöntemleri}

\subsubsection{Gövde ve kök uzunluğu}

Kontrol ve stres grubundaki buğday bitkilerinde kökle birleştiği yere kadar olan yeşil kısım gövde uzunluğu olarak $(\mathrm{cm})$ ve kök uzunluğu $(\mathrm{cm})$ cetvel ile ölçüldü (Şekil 1, Şekil 2a).

\subsubsection{Băğl su içeriğinin belirlenmesi}

Yaş ağırlık ölçümü için bitki fidelerinin olgun yaprakları (bayrak yaprak altındaki birinci yaprak) kullanılmıştır. Yaş ağırlığ 1 alınan bitkiler filtre kâğıtlarının arasına konularak 4 saat saf su içeren küvette bekletildikten sonra turgor ağılıkları kaydedilmiştir. Bu işlemin ardından yapraklar etüvde 70 ${ }^{\circ} \mathrm{C}^{\prime}$ de 24 saat kurutulduktan sonra kuru ağırlıkları saptanmıştır. Bu değerler formüle uygulanarak bağıl su içerikleri hesaplanmıştır (Hesaplamaya ilişkin formül
Eşitlik 1'de verilmiştir) (Smart ve Bingham 1974) (Şekil 2b)

$$
\begin{array}{ll}
\multicolumn{2}{c}{\text { BSİ=(YA-KA)/(TA-KA)X100 }} \\
\text { BSİ: Bağıl su içeriği } & \text { YA: Yaş ağılılık } \\
\text { TA: Turgor ağırlığı } & \text { KA: Kuru ağırlık }
\end{array}
$$

\subsubsection{Pigment içeriğinin belirlenmesi}

Toplam klorofil miktarı klorofil metre cihazı (Minolta SPAD-502, Osaka, Japan) ile gerçekleştirilmiştir (Peryea ve Kammereck 1997). Gelişmesini tamamlamış genç yapraklarda her bir grubun 5 saksısındaki 3 farklı fideden, 15 tekerrürlü olarak hasat günlerinde ölçüm yapılmıştır (Şekil 2c).

\subsubsection{Protein içeriğinin belirlenmesi}

Yaprak ve kök dokuları $1 \mathrm{mM}$ EDTA içeren $3 \mathrm{ml}$ $0.05 \mathrm{M}$ sodyum fosfat tamponunda ( $\mathrm{pH}$ 7.8) homojenize edildi. Özütler $+4{ }^{\circ} \mathrm{C}$ ' de 13000 rpm' de $30 \mathrm{dk}$ santrifüj edildikten sonra süpernatant kısmı protein analizinde kullanıldı. Tüm işlemler $+4{ }^{\circ} \mathrm{C}$ ' de gerçekleştirildi. 100 $\mu \mathrm{L}$ supernatant ve $5 \mathrm{ml}$ reaktif vortekste karıştırıldıktan $5 \mathrm{dk}$ ile $60 \mathrm{dk}$ arasinda $595 \mathrm{~nm}$ ' de spekrofotometrede köre karşı belirlendi (Şekil 2d) (Bradford, 1976).

\subsection{Antioksidan enzim aktivitelerinin belirlenmesi}

\subsubsection{Askorbat peroksidaz(APX; EC 1.11.1.11) aktivitesi}

Soğuk yaprak ve kök dokuları $1 \mathrm{ml} 2 \mathrm{mM}$ askorbik asit, $1 \mathrm{mM}$ EDTANa $2.2 \mathrm{H}_{2} \mathrm{O}$ içeren $50 \mathrm{mM}$ Na-P tamponu ( $\mathrm{pH}$ 7.8) ile homojenize edildi. Elde edilen süpernatant analizde kullanıldı (Nakano ve Asada, 1981) (ekstinksiyon katsayısı $2.8 \mathrm{mM}^{-1} \mathrm{~cm}^{-1}$ ). 1 enzim ünitesi, dakikada okside olan $1 \mu \mathrm{mol} \mathrm{ml^{-1 }}$ askorbat miktarıdır (Şekil 2i).

\subsubsection{Glutatyon redüktaz (GR; EC 1.6.4.2) aktivitesi}

NADPH varlığında okside glutatyon miktarındaki azalma 3 dk süre ile $340 \quad$ nm'deki absorbans azalmasindan hesaplandi. $\left(€=6,2 \mathrm{mM}^{-1} \mathrm{~cm}^{-1}\right) 1$ enzim ünitesi, dakikada okside olan glutatyon $\left(\mu \mathrm{mol} \mathrm{ml} \mathrm{ml}^{-1}\right)$ miktarıdır (Şekil 2k) (Foyer ve Halliwell, 1976).

\subsubsection{Peroksidaz (POX; EC 1.11.1.7) aktivitesi}

Aktivite 465 nm'de, DAB (3,3' Diaminobenzidine tetrahydrochloride) oksidasyonuyla absorbansta meydana gelen artış takip edilerek hesaplanır. Spesifik enzim aktivitesi dakikada tüketilen $\mu \mathrm{mol} \mathrm{ml^{-1 }} \mathrm{H}_{2} \mathrm{O}_{2}$ olarak ifade edilir (Şekil 2h) (Kanner ve Kinsella 1983).

\subsubsection{Katalaz (CAT; EC 1.11.1.6) aktivitesi}

$\mathrm{H}_{2} \mathrm{O}_{2}$ miktarındaki azalma; $240 \mathrm{~nm}$ ' de gösterdiğ maksimum absorbanstaki azalma saptanır. CAT 
aktivitesi dakikada harcanan $\mu$ mol ml-1 $\mathrm{H}_{2} \mathrm{O}_{2}$ olarak ifade edilir (Şekil 2m) (Bergmeyer, 1970).

\subsubsection{Lipit peroksidasyonu miktarının belirlenmesi}

Lipit peroksidasyonunun son ürünü olan malondialdehit (TBARS) seviyesinin ölçülmesi ile lipit peroksidasyon derecesi (nmol g yaş ağırlık ${ }^{-1}$ ) belirlenmektedir $\quad\left(€=155 \quad \mathrm{mM}^{-1} \quad \mathrm{~cm}^{-1}\right) \quad$ (Şekil 2e) (Madhava Rao ve Sresty, 2000).

\subsubsection{Hücre zarl geçirgenliği}

$100 \mathrm{mg}$ yaprak örneği $10 \mathrm{~mL}$ de-iyonize su içeren falkon tüplerine transfer edildikten sonra su banyosunda $\left(32{ }^{\circ} \mathrm{C}\right) 2$ saat inkübe edildi. Ortamın elektrik iletkenliği EC metre ile ölçüldü (EC1). Daha sonra örnekler 121 ${ }^{\circ} \mathrm{C}$ 'de $20 \mathrm{dk}$ boyunca tüm dokuların ölmesi ve elektrolitlerin dişa çıkması için otoklavlandı. Oda sıcaklığında $25{ }^{\circ} \mathrm{C}$ 'ye kadar soğutularak bu ortamdaki elektrik iletkenliği ölçüldü (EC2). Elektrolit sızıntısı (ES) aşağıdaki formüle uygulanarak hesaplandı. Ölçümler sırasında İsolab masa tipi EC metre cihazı kullanıldı (Şekil 2f) (Dionisio-Sese ve Tobita, 1998).

\subsubsection{Hidrojen peroksit analizi}

$138 \mu \mathrm{L} \quad \mathrm{H}_{2} \mathrm{SO}_{4}$ (Sülfirik Asit) \%100'lük soğuk aseton ile $100 \mathrm{~mL}$ ye tamamlanır. $0.1 \mathrm{~g}$ örnek $3 \mathrm{~mL}$ ile homojenize edilir. 4000 g'de $5 \mathrm{dk}$ santrifüjlenir. $138 \mu \mathrm{L}$ $\mathrm{H}_{2} \mathrm{SO}_{4} 100 \mathrm{~mL}$ saf su ile tamamlanır. Daha sonra çözeltinin içerisinde $250 \mathrm{mM} 0.01 \mathrm{~g}$ Ferrus amonium sülfat, $100 \mathrm{mM} 0.007 \mathrm{~g}$ Xsenol orange, $100 \mathrm{mM} 0.002 \mathrm{~g}$ sorbitol ve $1 \mathrm{~mL}$ etanol eklenir. Elde edilen süpernatant $30 \mathrm{dk}$ beklendikten sonra 550-800 nm'de polistren küvette köre (su) karşı okunur (Şekil 2g) (Cheeseman, 2006).

\subsubsection{Istatiksel analizler}

Tüm veriler ilk önce varyans analizine (ANOVA) göre test edildi. Sultan-95 ve Tosunbey çeşitlerinin yaprak dokusunda, incelenen parametrelerin verilerine ait tek yönlü varyans analizi (ANOVA) gerçekleştirildi.

\section{Bulgular ve Tartışma}

\subsection{Kök}

Sultan-95 çeşidinde gövde uzunlukları kontrole kıyasla kuraklık (D) uygulaması ile \%14 anlamlı şekilde azalırken Glisin-Betain (GB) ve $\mathrm{D}+\mathrm{GB}$ uygulamalarında sırasıyla $\% 10$ ve $\% 3$ artmıştır. Tosunbey çeşidinde ise kontrole kıyasla D uygulaması kök uzunluğunu anlamlı şekilde \%21 azaltırken GB uygulaması anlamlı şekilde \%20 arttırmıştır.
Sonuçlar her iki çeşidin kuraklık ile meydana gelen kök uzunluğundaki azalmayı GB uygulaması ile telafi edebildiklerini göstermektedir. Kontrole kıyasla, tek başına GB uygulaması ise sadece kuraklığa dayanıklı Tosunbey çeşidinde önemli bir atışa neden olmuştur. Diğer yandan, GB uygulamasının kuraklık etkisindeki her iki çeşide ait fidelerde kök uzunluklarının kontrol bitkilerle aynı seviyede olmasını sağladığı belirlenmiştir.

\subsection{Gövde}

Gövde uzunlukları kurağa duyarlı Sultan-95 çeşidinde tüm uygulamalar ile azalmıştır. Bu azalışlar kontrole kiyasla $\mathrm{D}, \mathrm{GB}$ ve $\mathrm{D}+\mathrm{GB}$ gruplarında sirasiyla $\% 5$, $\% 7,6$ ve $\% 9,2$ 'dir. Bunlardan sadece $\mathrm{D}+\mathrm{GB}$ grubundaki azalma istatistiksel olarak anlamlıdır. Buna zit olarak Tosunbey çeşidinde ise tüm uygulamalar ile gövde uzunluklarının arttığı belirlenmiştir. $\mathrm{Bu}$ artışlar kontrole kıyasla $\mathrm{D}, \mathrm{GB}$ ve $\mathrm{D}+\mathrm{GB}$ gruplarında sirasiyla $\% 2, \% 2,5$ ve $\% 1,7$ olup istatistiksel olarak anlamlı değildir.

Sonuçlar kuraklığa dayanıklı çeşit olan Tosunbey’ in tüm uygulamalarla dayanıklılığını koruduğunu göstermektedir.

\subsection{Toplam protein miktarl}

Kuraklık uygulaması toplam protein miktarını Sultan-95 çeşidinde kontrole kıyasla \%26 arttırırken, GB uygulamasıyla \%76 artmıştır. $\mathrm{Bu}$ çeşitte $\mathrm{D}+\mathrm{GB}$ uygulamasının protein miktarını kontrole kıyasla 2 kat arttığ çeşidinde ise D uygulamasıyla kontrole kıyasla \%15 azaltmıştır. Bununla birlikte $\mathrm{GB}$ ve $\mathrm{D}+\mathrm{GB}$ uygulamalarında ise sırasıyla $\% 21$ ve $\% 9$ artış tespit edilmiştir.

Buna göre her iki çeşitte protein miktarının GB ve GB+D uygulamalariyla kontrole kiyasla istatistiksel olarak anlamlı şekilde arttığı ve bu artışın Sultan-95 çeşidinde daha yüksek olduğu belirlenmiştir.

\subsection{Bağıl su içeriği}

Kuraklık uygulaması Sultan-95 çeşidinde bağıl su içeriğini kontrole kıyasla \%30, Tosunbey çeşidinde ise $\% 27$ azaltmıştır. GB ve GB+D uygulamaları BSI'yi her iki çeşitte de kontrol bitkilerin seviyesine getirmiştir.

Sonuç olarak GB+D uygulamasında Tosunbey çeşidinin BSİ' yi korumada Sultan-95'ten daha başarılı olduğu belirlenmiştir.

\subsection{Toplam klorofil miktarl}

Sultan-95 çeşidinde tüm uygulamalar ile toplam klorofil miktarı azalmıştır. Bu azalışlar kontrole kıyasla D, GB, D+GB grupları için sırasıyla $\% 30, \% 15, \% 10$ oranındadır. Kuraklığa dayanıklı Tosunbey çeşidinde ise 
D uygulamasıyla \%8 azalan klorofil miktarı diğer uygulamalar ile artmıştır. Özellikle $\mathrm{D}+\mathrm{GB}$ uygulaması ile bu artış 1,2 kat olarak belirlenmiştir.

Sonuçlar Tosunbey çeşidinin, Sultan-95 çeşidine kıyasla kuraklığın neden olduğu oksidatif hasara bağlı klorozisten daha iyi korunduğuna ve GB uygulamasının destekleyici etkisine işaret etmektedir.

\subsection{Hücre zarl geçirgenliği}

Tüm uygulamaların Sultan-95 çeşidinde hücre zarı geçirgenliğinde anlamlı bir değişime neden olmadığ belirlenmiştir. İlginç şekilde, Tosunbey çeşidinde ise tüm uygulamalar HZG'yi azaltmıştır. Bu azalmalar D, GB, D+GB uygulamalarında kontrole kiyasla sırasıyla $\% 20, \% 14$ ve $\% 24$ 'tür.

Sonuçta, Sultan-95 çeşidine kıyasla Tosunbey çeşidinin GB uygulamasıyla kuraklığa bağlı membran hasarını sınırlayabildiği belirlenmiştir.

\subsection{Hidrojen peroksit miktarı}

Sultan-95 çeşidinde $\mathrm{H}_{2} \mathrm{O}_{2}$ miktarı $\mathrm{D}$ ve GB uygulamalarında kontrole kiyasla sirasiyla $\% 10$ ve $\% 14$ artmış, $\mathrm{GB}+\mathrm{D}$ uygulamasıly bu artış kontrol seviyesinde sınırlanmıştır. Tosunbey çeşidinde ise $\mathrm{D}$ uygulamasıla \%26 artan $\mathrm{H}_{2} \mathrm{O}_{2}$ miktarı ise her iki GB uygulamasiyla azalarak kontrol seviyesinde sınırlanmıştır.

Sonuçlar her iki çeşitte GB ilavesinin $\mathrm{H}_{2} \mathrm{O}_{2}$ miktarını azalttığına ve bu azalmanın Tosunbey çeşidinde daha belirgin olduğuna işaret etmektedir.

\subsection{Lipit peroksidasyon miktarı}

Lipit peroksidasyon miktarı D uygulaması ile Sultan-95 çeşidinde kontrole kıyasla \%20 artarken, diğer uygulamalar ile azalmıştır. $\mathrm{Bu}$ azalma özellikle D+GB uygulamasında $\% 13$ oranındadır. Tosunbey çeşidinde ise $\mathrm{D}$ uygulamasında kontrole kıyasla \%3 azalan lipit peroksidasyon miktarı D+GB uygulaması ile kuraklık sonucu meydana gelen azalmayı telafi ederek $\% 3$ artmıştır.

Sonuç olarak kuraklık ile her iki çeşitte artan lipit peroksidasyon miktarı GB ilavesiyle azalmıştır. $\mathrm{Bu}$ azalma duyarlı çeşitte daha fazladır.

\subsection{Glutatyon redüktaz miktarl}

Kuraklığa hassas Sultan-95 çeşidinde GR aktivitesi kuraklık uygulaması ile kontrole kıyasla \%9 artmıştır. Öte yandan diğer tüm uygulamalarda azalan değerler saptanmıştır. Özellikle D+GB uygulamasıyla bu azalma
$\% 40$ olarak belirlenmiştir. Tosunbey çeşidinde de Sultan-95 çeşidindeki gibi kontrole kıyasla kuraklık ile $\% 16$ artan GR aktivitesini GB ve D+GB uygulamalarında sırasıyla $\% 30$ ve $\% 18$ oranında azalmalar takip etmiştir.

Sonuçlar her iki çeşitte kuraklık ile ortaya çıkan oksidatif hasarla baş etmede GR aktivitesinin arttığını, ancak GB ilavesinin GR aktivitelerini kontrole kıyasla arttırmadığına işaret etmektedir.

\subsection{Katalaz aktivitesi}

Katalaz aktivitesi Sultan-95 çeşidinde D ve GB uygulamasiyla kontrole kiyasla sirasiyla $\% 20$ ve $\% 22$ azalmıştır. D+GB uygulama grubunda ise \%32 artmıştır. Tosunbey çeşidinde tüm uygulamalar katalaz aktivitesini \%2-4 oranında arttırmıştır.

Sonuç olarak GB ilavesinin duyarlı çeşitte kuraklık ile artan $\mathrm{H}_{2} \mathrm{O}_{2}$ 'i temizlemede CAT aktivitelerini arttırdığı, duyarlı çeşitte ise anlamlı bir etkiye sahip olmadığı belirlenmiştir.

\subsection{Askorbat Peroksidaz aktivitesi}

Sultan-95 çeşidinde APX aktivitesi tüm uygulamalar ile artmıştır. Özelikle D+GB uygulamamasında kontrole kıyasla \%66 artış tespit ediliştir. Tosunbey çeşidinde ise APX aktivitesi D uygulaması ile kontrole kıyasla 2 kat artarken, $\mathrm{D}+\mathrm{GB}$ uygulamasında bu artış \%14 seviyesindedir.

Sonuç olarak duyarlı çeşitte GB ilavesinin $\mathrm{H}_{2} \mathrm{O}_{2}$ 'yi temizlemede APX aktivitesini neredeyse 2 kat arttırdı ğı, tersine aynı uygulamanın dayanıklı çeşitte sınırlı bir artış gösterdiği belirlenmiştir.

\subsection{Peroksidaz aktivitesi}

Peroksidaz aktivitesi kuraklığa hassas çeşitte D uygulaması ile kontrole kıyasla \%30 artmıştır. Aynı çeşitte GB uygulamasında 1.5 kat artan POX aktivitesi, $\mathrm{D}+\mathrm{GB}$ uygulaması ile \%8 azalmıştır. Tosunbey çeşidinde ise kontrole kıyasla D ve GB uygulaması sirasiyla $\% 21$ ve $\% 51$ oranında azalan POX aktivitesi saptanmıştır.

Sonuçlarımız Sultan-95 çeşidinin kuraklık ile artan $\mathrm{H}_{2} \mathrm{O}_{2}$ 'in temizlenmesinde GB ilavesinin etkili olmadığına, kuraklığa dayanıklı Tosunbey çeşidinin ise pozitif etkilendiğine işaret etmektedir. $\mathrm{Bu}$ sonuç $\mathrm{H}_{2} \mathrm{O}_{2}$ 'nin temizlenmesinde GB ilavesi ile Tosunbey çeşidinde POX aktivitesinin indüklendiğini göstermiştir. 


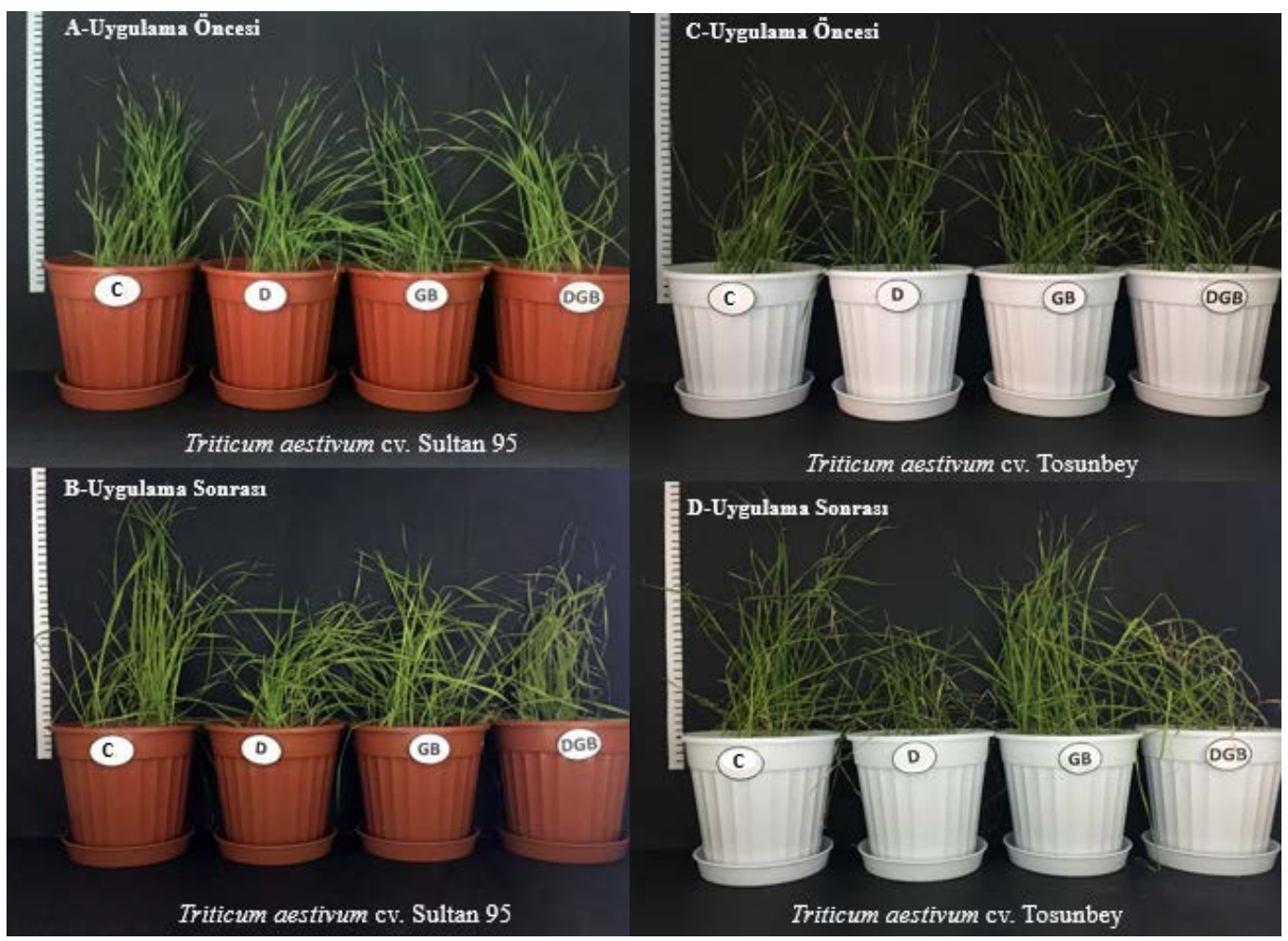

Şekil 1. Kuraklık uygulaması ve Glisin-Betain'in buğday fideleri üzerindeki etkileri. A: Triticum aestivum cv. Sultan-95 uygulama öncesi B: Triticum aestivum cv. Sultan-95 uygulama sonras1 C: Triticum aestivum cv. Tosunbey uygulama öncesi D: Triticum aestivum cv. Tosunbey uygulama sonrası (C: Kontrol D: Kuraklık GB: Glisin-Betain DGB: Kuraklık + Glisin-Betain).

Figure 1. The effects of drought treatment and Glycine-Betaine on wheat seedlings. A: Triticum aestivum cv. Sultan-95 before treatment B: Triticum aestivum cv. Sultan-95 after treatment C: Triticum aestivum cv. Tosunbey before treatment D: Triticum aestivum cv. Tosunbey after treatment (C: Control D: Drought GB: Glycine-Betaine DGB: Drought + Glycine-Betaine).

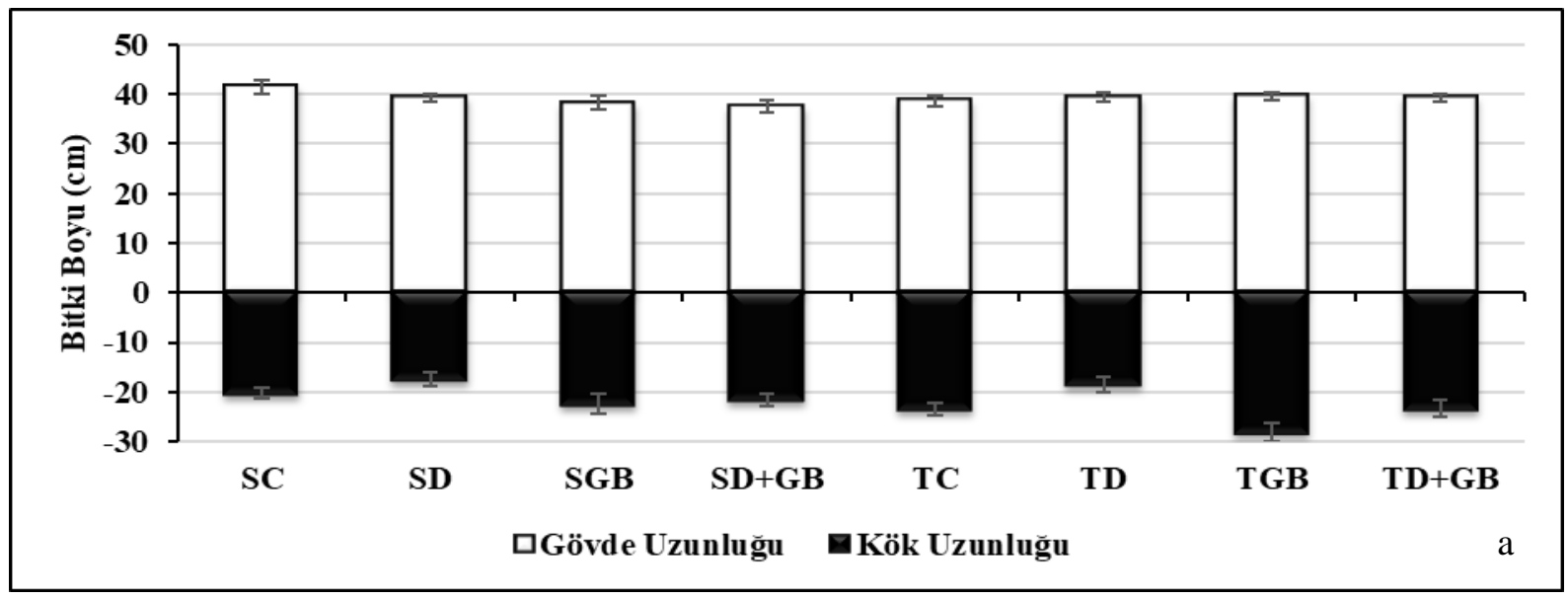




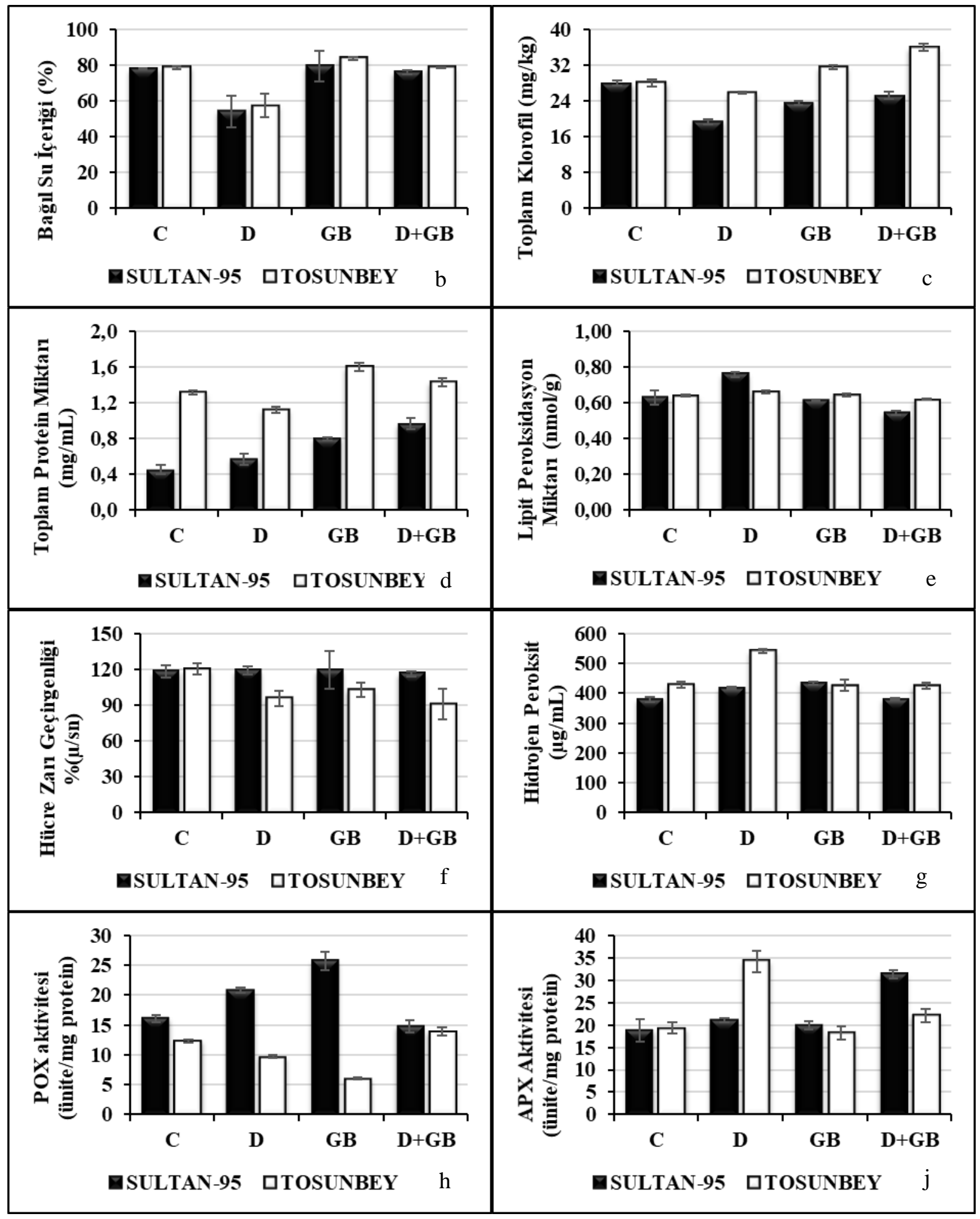




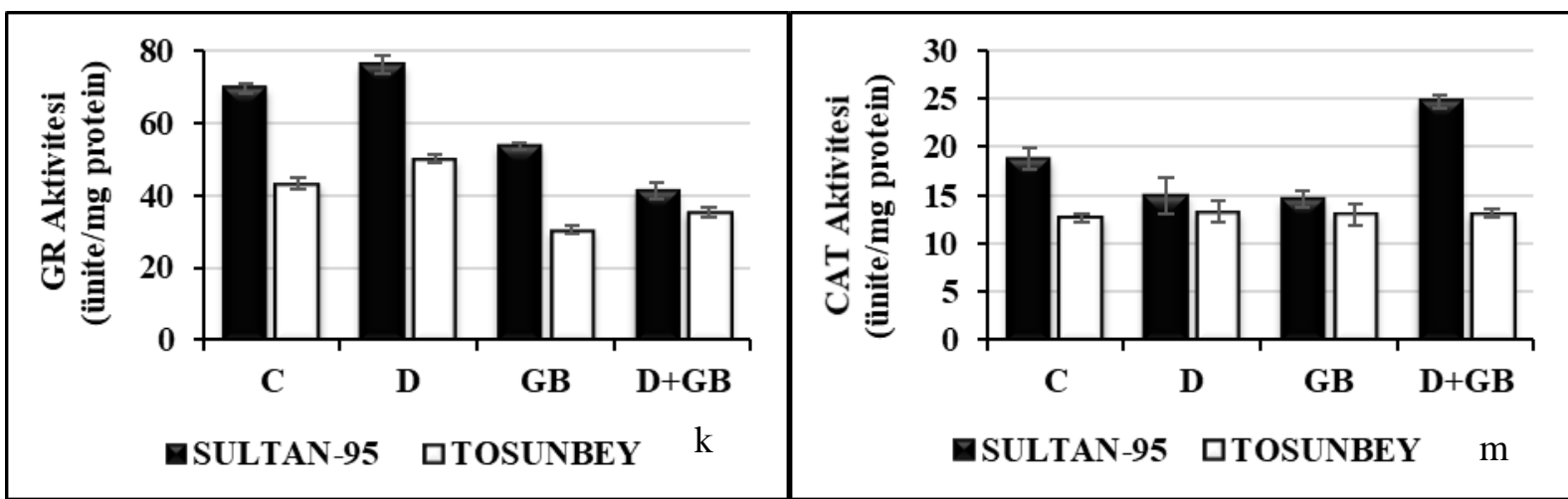

Şekil 2. Kuraklık uygulaması ve Glisin-Betain'in kök ve gövde uzunluğu (Tosunbey: T, Sultan-95: S), bağıl su içeriği, toplam klorofil miktarı, protein miktarı, hücre zarı geçirgenliği (HZG), hidrojen peroksit $\left(\mathrm{H}_{2} \mathrm{O}_{2}\right)$, lipid peroksidasyon (TBARS) ve antioksidan enzimlerin aktiviteleri (POX, APX, GR, CAT) üzerine etkileri. C: Kontrol D: Kuraklık GB: Glisin-Betain DGB: Kuraklık+ Glisin-Betain.

Figure 2. The effects of Glycine-Betaine treatment and drought stress on shoot and root elongation, relative water content, total chlorophyll content, protein content, cell membrane permeability, hydrogen peroxide $\left(\mathrm{H}_{2} \mathrm{O}_{2}\right)$ lipid peroxidation (TBARS) and activities of antioxidant enzymes (POX, APX, GR, CAT). C: Control D: Drought GB: Glycine-Betaine DGB: Drought+ Glycine-Betaine.

\section{Sonuç}

Kuraklık, bitki büyümesini ve verimini en çok olumsuz etkileyen abiyotik streslerden biridir. Buğday gibi stratejik öneme sahip tahıllar kuraklık stresinden olumsuz etkilendiklerinde biyokütle ve verim azalır (Liu ve ark., 2019). Bu çalışmada 5 mM GB püskürtülmesinin kuraklığa farklı toleransa sahip iki buğday çeşidinin antioksidan sistemine etkisi araştırılmıştır. Kuraklık altındaki buğday fidelerine GB ilavesi her iki çeşitte kök uzunluğundaki azalmayı telafi etmiş, gövde uzunluğu ise sadece kurağa dayanıklı genotipte korunduğu belirlenmiştir. Ek olarak Sultan-95 çeşidinde daha yüksek olmak üzere her iki çeşitte protein miktarı GB uygulamalarıyla artmıştır. Diğer yandan GB ilavesinin Tosunbey çeşidini kuraklık kaynaklı klorozisten Sultan-95'e kıyasla daha iyi koruduğu belirlenmiştir. Bunun nedeni GB ilavesiyle artan $\mathrm{H}_{2} \mathrm{O}_{2}$ seviyelerini ve lipit peroksidasyonu azaltan Tosunbey çeşidinin membran stabilitesini hassas çeşide kıyasla daha iyi koruması olabilir. Buğdayda kuraklık stresiyle GB'nin arttığı, TBARS ve $\mathrm{H}_{2} \mathrm{O}_{2}$ 'nin azaldığ 1 rapor edilmiștir (Shanazari ve ark. 2018). Sonuçlarımız Tosunbey'de membran stabilitesinin korunmasinda kuraklıkla artan $\mathrm{H}_{2} \mathrm{O}_{2}$ 'nin $\mathrm{POX}$ aktivitesinin indüklenmesine bağlı detoksifikasyonuyla ilişkili olduğuna işaret etmektedir. Kuraklığa hassas çeşit Sultan-95'te ise kuraklıkla ortaya çıkan oksidatif stresin bastırılmasında CAT ve APX aktivitelerinin etkili şekilde kullanıldığı belirlenmiştir. Bu durum kurağa zıt toleranslı iki çeşit arasında farklı $\mathrm{H}_{2} \mathrm{O}_{2}$ temizlenme mekanizmalarına işaret etmektedir. İlginç şekilde her iki çeşitte de GB ilavesinin GR aktiviteleri üzerinde etkisiz olduğu saptanmıştır. Kuraklığa dayanıklılıkta antioksidan savunma sisteminde etkili bir mekanizma olan askorbat-glutatyon yolağında hem APX hem de GR'nin etkili çalıştığı bilinmektedir (Lascano ve ark., 2001). Tosunbey çeşidi bu yolak yerine POX aktivitesini arttırarak oksidatif stresin etkisini azaltmaktadır. Sultan-95'in ise sadece APX aktivitesini arttırabilmesi, bu çeşidin kuraklığa hassas doğasına ilişkin temel problemlerden birisinin GR aktivitesindeki yetersizlik olabileceğini düşündürmektedir.

Kuraklık (Shanazari ve ark., 2018) ve tuzluluk (Ciarmiello ve ark., 2018) gibi stresler buğdayda GB birikimini teşvik ederek ozmotik dengeyi sağlamakta ve oksidatif stresi azaltmaktadır. Ayrıca eksojen GB ilavesinin buğdayda antioksidan enzim aktivitelerini arttırdığı, TBARS ve $\mathrm{H}_{2} \mathrm{O}_{2}$ miktarını azalttığı ve sonuçta membran stabilitesinin korunduğu gösterilmiştir (Ahmed ve ark., 2019). Benzer şekilde, araştırmamızda eksojen GB uygulaması kuraklık stresi altındaki buğday bitkilerinde TBARS ve $\mathrm{H}_{2} \mathrm{O}_{2}$ 'i azaltarak her iki çeșitte oksidatif strese bağlı lipit peroksidasyonu da azaltmış ve böylece oksidatif stresten koruma sağlamıştır. Bu korumanın Sultan-95'te daha belirgin olması Tosunbey için daha yüksek bir stres eşiğine işaret ediyor olabilir.

\section{Teşekkür}

Araştırma süresince yardımlarından dolayı Dr. Belma ACAR'a teşekkür ederiz. 


\section{Kaynaklar}

Ahmed, N., Zhang, Y., Li, K., Zhou, Y., Zhang, M., Li, Z., 2019. Exogenous application of glycine betaine improved water use efficiency in winter wheat (Triticum aestivum L.) via modulating photosynthetic efficiency and antioxidative capacity under conventional and limited irrigation conditions. The Crop Journal, 7(5), 635-650. doi: https://doi.org/10.1016/j.cj.2019.03.004

Alves, A.A., Setter, T.L., 2004. Abscisic acid accumulation and osmotic adjustment in cassava under water deficit. Environ. Exp. Bot., 51 (3) (2004), pp. 259-271.

Beauchamp, C., Fridovich, I. 1971. Superoxide dismutase: improved assays and an assay applicable to acrylamide gels. Analytical Biochemistry, 44,276287. doi.org/10.1016/0003-2697(71)90370-8.

Bergmeyer, N., 1970. Methoden der enzymatischen analyse. Akademia Verlag, Berlin, Cilt 1:636-647.

Blum, A., 2017. Osmotic adjustment is a prime drought stress adaptive engine in support of plant production. Plant Cell Environ., 40 (1) (2017), pp. 4-10. Doi: 10.1111/pce.12800.

Bradford, M.M., 1976. A rapid and sensitive method for the quantitation of microgram quantities of protein utilizing the principle of protein-dye binding. Analytical Biochemistry, 72(1-2), 248-254. doi.org/10.1016/0003-2697(76)90527-3.

Büyük İ., Semra-Aydın S., Aras S., 2012. Bitkilerin stres koşullarına verdiği moleküler cevaplar. Türk Hijyen ve Deneysel Biyoloji Dergisi, 69(2): 97-110. doi: 10.5505/TurkHijyen.2012.40316.

Cattivelli, L., Rizza, F., Badeck, F. W., 2008. Drought tolerance improvement in crop plants: an integrated view from breeding to genomics. Field Crops Research 105, 1-14. doi.org/10.1016/j.fcr.2007.07.004.

Cheeseman, J.M., 2006. Hydrogen peroxide concentrations in leaves under natural conditions. Journal of Experimental Botany, 57, 2435-44 pp.

Chen, T.H.H., Murata, N., 2008. Glycinebetaine: An Effective Protectant Against Abiotic Stress in Plants, Trends Plant Sci, 13, 499-505.

Ciarmiello, L.F., Di Maro, A., Woodrow, P., Annunziata, M.G., Kafantaris, I., Mirto, A., Carillo, P., 2018. Unveiling the enigmatic structure of TdCMO transcripts in durum wheat. Agronomy, 8(11), 270. doi:10.3390/agronomy8110270.

Cummins, A.G., Roberts-Thomson, I.C., 2009. Prevalence of celiac disease in the Asia-Pacific region. Journal of Gastroenterology and Hepatology, 24(8), 1347-1351. doi.10.1111/j.14401746.2009.05932.

Dat, J., Vandenabeele, S., Vranová, E., Van Montagu, M., Inzé, D., Van Breusegem, F., 2000. Dual action of the active oxygen species during plant stress responses. Cell Mol Life Sci 57: 779-795. doi: 10.1007/s000180050041.

Demirbaş S., Acar O., 2008. Superoxide Dismutase and Peroxidase Activities from Antioxidative Enzymes in Helianthus annuus L. Roots During Orobanche cumana Wallr. Penetration. Fresenius Environ. Bull., 17 (8a): 1038-1044.

Dionisio-Sese, M. L., Tobita, S., 1998. Antioxidant responses of rice seedlings to salinity stress. Plant Science, 135: 1-9. doi.org/10.1016/S01689452(98)00025-9.

Dolferus, R., Ji, X., Richards, R. A., 2011. Abiotic stress and control of grain number in cereals. Plant Science 181, 331-341. doi: 10.1016/j.plantsci.2011.05.015.

Dong, B., Zheng, X., Liu, H., Able, JA., Yang, H., Zhao, H., Zhang, M., Qiao, Y., Wang, Y., Liu, M., 2017. Effects of drought stress on pollen sterility, grain yield, abscisic acid and protective enzymes in two winter wheat cultivars. Frontiers in Plant Science. doi: 10.3389/fpls.2017.01008.

FAOSTAT., 2020. Food and agriculture organization of the united nations. Available from URL:http://www.fao.org/faostat/en/\#data/QC (Erişim Tarihi: 26 Temmuz 2020).

Farooq, M., Hussain, M., Siddique, K. H. M.., 2014. Drought stress in wheat during flowering and grainfilling periods. Critical Reviews in Plant Sci 33, 331-349. doi.org/10.1080/07352689.2014.875291.

Foyer, C.H., Halliwell, B., 1976. Presence of glutathione and glutathione reductase in chloroplasts: a proposed role in ascorbic acid metabolism. Planta, 133: 21-25.

Gadallah, M.A.A., 1999. Effects of proline and glycinebetaine on vicia faba response to salt stress. Biol. Plant. 249-257. doi.org/10.1023/A:1002164719609.

Gençtan, T., Akar, T., Öktem, A., Soylu, S., Hurma, H., Balkan, A., Sürek, H., 2020. Tahıl üretimimizin mevcut durumu ve geleceği. Türkiye Ziraat Mühendisliği IX. Teknik Kongresi Bildiriler Kitab11,371 .

Hare, P.D., Cress, W.A., Van Staden, J., 1998. Dissecting the roles of osmolyte accumulation during stress. plant, Cell and Environment 21, 535553. doi.org/10.1046/j.1365-3040.1998.00309.x.

Jaganathan, D., Ramasamy, K., Sellamuthu, G., Jayabalan, S., Venkataraman, G., 2018. CRISPR for crop improvement: an update review. Frontiers in Plant Science, 9, 985. doi: 10.3389/fpls.2018.00985.

Kacar, B., Katkat, A. V., Öztürk, Ş., 2002. Bitki Fizyolojisi. Uludağ Üniversitesi Güçlendirme Vakfı Yayın No: 198, Vipaş Yayın No:74., Bursa.

Kanner, J., Kinsella, J. E., 1983. Lipid deterioration initiated by phagocytic cells in muscle foods: $\beta$ carotene destruction by a myeloperoxidase-hydrogen peroxide halide system. Journal of Agricultural and 
Food Chemistry, 31,370-376. doi.org/10.1007/BF02534548.

Lascano, H.R., Antonicelli, G.E., Luna, C.M., Melchiorre, M.N., Gómez, L.D., Racca, R.W., Casano, L.M. 2001. Antioxidant system response of different wheat cultivars under drought: field and in vitro studies. Functional Plant Biology, 28(11), 1095-1102. https://doi.org/10.1071/PP01061.

Liu, Y., Guo, X., Ma, M., Jiang, X., 2019. Effects of drought and rewatering on growth and physiological characteristics of maize seedlings and regulation of root-sourced Aba. Agricultural Research In The Arid Areas, 37(1), 187-193.

Ma, J., Li, R., Wang, H., Li, D., Wang, X., Zhang, Y., Zhen, W., Duan, H., Yan, G., Li, Y., 2017. Transcriptomics analyses reveal wheat responses to drought stress during reproductive stages under field conditions. Frontiers in Plant Science 8, 592. doi.org/10.3389/fpls.2017.00592.

Madhava, R.K.V., Sresty, T.V.S., 2000. Antioxidative parameters in the seedlings of pigeonpea (cajanus cajan l. millspaugh) in response to $\mathrm{zn}$ and ni stresses. Plant Sci., 157: 113-128. doi: 10.1016/s01689452(00)00273-9.

Mickelbart, M.V., Hasegawa, P.M., Bailey-Serres, J., 2015. Genetic mechanisms of abiotic stress tolerance that translate to crop yield stability. Nature Reviews Genetics, 16: 237-251. doi: 10.1038 / nr.

Moller, I.M., Jensen, P.E., Hansson, A., 2007. Oxidative modifications to cellular components in plants. Annu Rev Plant Biol, 58, 459-81. doi: 10.1146/annurev.arplant.58.032806.103946.

Mwadzingeni, L., Shimelis, H., Dube, E., Laing, M. D., Tsilo, T. J., 2016. Breeding wheat for drought tolerance: progress and technologies. Journal of Integrative Agriculture 15, 935-943. doi: 10.3389/fpls.2016.01276.

Nakano, Y., Asada, K., 1981. Hydrogen peroxide is Scavenged by ascorbate-specific peroxidase in spinach chloroplasts plant. Cell Physiol, 22(3), 867880. doi:10.1093/oxfordjournals.pcp.a076232.

Peryea, F.J., Kammereck, R., 1997. Use of Minolta Spad-502 chlorophyll meter to quantify the effectiveness of mid-summer trunk injection of iron on chlorotic pear trees. Journal of plant Nutrition, 20(11):1457-1463. doi.org/10.1080/01904169709365348.

Shanazari, M., Golkar, P., Mirmohammady Maibody, A.M., 2018. Effects of drought stress on some agronomic and bio-physiological traits of Trititicum aestivum, Triticale, and Tritipyrum genotypes. Archives of Agronomy and Soil Science, 64(14), 2005-2018. doi: 10.1080/03650340.2018.1472377.

Smart, R.E., Bingham, G.E., 1974. Rapid estimates of relative water content. plant physiology, 53(2):258 260. doi: 10.1104/pp.53.2.258.

TMO., 2018. Toprak mahsulleri ofisi. Available from URL:http://www.tmo.gov.tr/Upload/Document/hubu batsektorraporu2018.pdf (Erişim Tarihi: 26 Temmuz 2020).

Verbruggen, N., Hermans, C., 2008. Proline accumulation in plants: a review Amino Acids, 35 (4) (2008), pp. 753-759. doi: 10.1007/s00726-0080061-6. 